\title{
SERIES INTRODUCTION \\ Greek Oratory
}

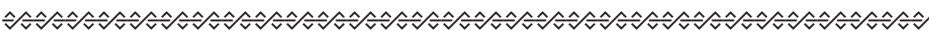

\section{By Michael Gagarin}

\section{ORATORY IN CLASSICAL ATHENS}

From as early as Homer (and undoubtedly much earlier) the Greeks placed a high value on effective speaking. Even Achilles, whose greatness was primarily established on the battlefield, was brought up to be "a speaker of words and a doer of deeds" (Iliad 9.443); and Athenian leaders of the sixth and fifth centuries, ${ }^{1}$ such as Solon, Themistocles, and Pericles, were all accomplished orators. Most Greek literary genres-notably epic, tragedy, and history-underscore the importance of oratory by their inclusion of set speeches. The formal pleadings of the envoys to Achilles in the Iliad, the messenger speeches in tragedy reporting events like the battle of Salamis in Aeschylus' Persians or the gruesome death of Pentheus in Euripides' Bacchae, and the powerful political oratory of Pericles' funeral oration in Thucydides are but a few of the most notable examples of the Greeks' never-ending fascination with formal public speaking, which was to reach its height in the public oratory of the fourth century.

In early times, oratory was not a specialized subject of study but was learned by practice and example. The formal study of rhetoric as an "art" (technē) began, we are told, in the middle of the fifth century in Sicily with the work of Corax and his pupil Tisias. ${ }^{2}$ These two are scarcely more than names to us, but

${ }^{1}$ All dates in this volume are $\mathrm{BC}$ unless the contrary is either indicated or obvious.

${ }^{2}$ See Kennedy 1963: 26-51. Cole I99I has challenged this traditional picture, arguing that the term "rhetoric" was coined by Plato to designate and denigrate an activity he strongly opposed. Cole's own reconstruction is not 
another famous Sicilian, Gorgias of Leontini (ca. 490-390), developed a new style of argument and is reported to have dazzled the Athenians with a speech delivered when he visited Athens in 427. Gorgias initiated the practice, which continued into the early fourth century, of composing speeches for mythical or imaginary occasions. The surviving examples reveal a lively intellectual climate in the late fifth and early fourth centuries, in which oratory served to display new ideas, new forms of expression, and new methods of argument. ${ }^{3}$ This tradition of "intellectual" oratory was continued by the fourth-century educator Isocrates and played a large role in later Greek and Roman education.

In addition to this intellectual oratory, at about the same time the practice also began of writing speeches for real occasions in public life, which we may designate "practical" oratory. For centuries Athenians had been delivering speeches in public settings (primarily the courts and the Assembly), but these had always been composed and delivered impromptu, without being written down and thus without being preserved. The practice of writing speeches began in the courts and then expanded to include the Assembly and other settings. Athens was one of the leading cities of Greece in the fifth and fourth centuries, and its political and legal systems depended on direct participation by a large number of citizens; all important decisions were made by these large bodies, and the primary means of influencing these decisions was oratory. ${ }^{4}$ Thus, it is not surprising that oratory flourished in Athens, ${ }^{5}$ but it may not be immediately obvious why it should be written down.

without problems, but he does well to remind us how thoroughly the traditional view of rhetoric depends on one of its most ardent opponents.

${ }^{3}$ Of these only Antiphon's Tetralogies are included in this series. Gorgias' Helen and Palamedes, Alcidamas' Odysseus, and Antisthenes' Ajax and Odysseus are translated in Gagarin and Woodruff 1995.

${ }^{4}$ Yunis 1996 has a good treatment of political oratory from Pericles to Demosthenes.

${ }^{5}$ All our evidence for practical oratory comes from Athens, with the exception of Isocrates I9, written for a trial in Aegina. Many speeches were undoubtedly delivered in courts and political forums in other Greek cities, but it may be that such speeches were written down only in Athens. 
The pivotal figure in this development was Antiphon, one of the fifth-century intellectuals who are often grouped together un-

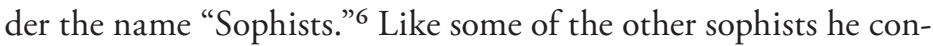
tributed to the intellectual oratory of the period, but he also had a strong practical interest in law. At the same time, Antiphon had an aversion to public speaking and did not directly involve himself in legal or political affairs (Thucydides 8.68). However, he began giving general advice to other citizens who were engaged in litigation and were thus expected to address the court themselves. As this practice grew, Antiphon went further, and around 430 he began writing out whole speeches for others to memorize and deliver. Thus began the practice of "logography," which continued through the next century and beyond. ${ }^{7}$ Logography particularly appealed to men like Lysias, who were metics, or noncitizen residents of Athens. Since they were not Athenian citizens, they were barred from direct participation in public life, but they could contribute by writing speeches for others.

Antiphon was also the first (to our knowledge) to write down a speech he would himself deliver, writing the speech for his own defense at his trial for treason in 4II. His motive was probably to publicize and preserve his views, and others continued this practice of writing down speeches they would themselves deliver in the courts and (more rarely) the Assembly. ${ }^{8}$ Finally, one other type of practical oratory was the special tribute delivered on certain important public occasions, the best known of which is the funeral oration. It is convenient to designate these three types of

'The term "sophist" was loosely used through the fifth and fourth centuries to designate various intellectuals and orators, but under the influence of Plato, who attacked certain figures under this name, the term is now used of a specific group of thinkers; see Kerferd i98I.

${ }^{7}$ For Antiphon as the first to write speeches, see Photius, Bibliotheca 486a7-II and [Plut.], Moralia 832c-d. The latest extant speech can be dated to 320 , but we know that at least one orator, Dinarchus, continued the practice after that date.

${ }^{8}$ Unlike forensic speeches, speeches for delivery in the Assembly were usually not composed beforehand in writing, since the speaker could not know exactly when or in what context he would be speaking; see further Trevett 1996. 
oratory by the terms Aristotle later uses: forensic (for the courts), deliberative (for the Assembly), and epideictic (for display). ${ }^{9}$

\section{THE ORATORS}

In the century from about 420 to 320 , dozens-perhaps even hundreds - of now unknown orators and logographers must have composed speeches that are now lost, but only ten of these men were selected for preservation and study by ancient scholars, and only works collected under the names of these ten have been preserved. Some of these works are undoubtedly spurious, though in most cases they are fourth-century works by a different author rather than later "forgeries." Indeed, modern scholars suspect that as many as seven of the speeches attributed to Demosthenes may have been written by Apollodorus, son of Pasion, who is sometimes called "the eleventh orator." ${ }^{10}$ Including these speeches among the works of Demosthenes may have been an honest mistake, or perhaps a bookseller felt he could sell more copies of these speeches if they were attributed to a more famous orator.

In alphabetical order the Ten Orators are as follows: ${ }^{11}$

- Aeschines (ca. 390-ca. 322) rose from obscure origins to become an important Athenian political figure, first an ally, then a bitter enemy of Demosthenes. His three speeches all concern major public issues. The best known of these (Aes. 3) was delivered at the trial in 330, when Demosthenes responded with $O n$ the Crown (Dem. I8). Aeschines lost the case and was forced to leave Athens and live the rest of his life in exile.

${ }^{9}$ Rhetoric I.3. Intellectual orations, like Gorgias' Helen, do not easily fit into Aristotle's classification. For a fuller (but still brief) introduction to Attic oratory and the orators, see Edwards 1994.

${ }^{10}$ See Trevett 1992.

${ }^{11}$ The Loeb volumes of Minor Attic Orators also include the prominent Athenian political figure Demades (ca. 385-319), who was not one of the Ten; but the only speech that has come down to us under his name is a later forgery. It is possible that Demades and other fourth-century politicians who had a high reputation for public speaking did not put any speeches in writing, especially if they rarely spoke in the courts (see above n. 8). 
- Andocides (ca. 440-ca. 390) is best known for his role in the scandal of 4I5, when just before the departure of the fateful Athenian expedition to Sicily during the Peloponnesian War (43I-404), a band of young men mutilated statues of Hermes, and at the same time information was revealed about the secret rites of Demeter. Andocides was exiled but later returned. Two of the four speeches in his name give us a contemporary view of the scandal: one pleads for his return, the other argues against a second period of exile.

- antiphon (ca. 480-4II), as already noted, wrote forensic speeches for others and only once spoke himself. In 4II he participated in an oligarchic coup by a group of 400 , and when the democrats regained power he was tried for treason and executed. His six surviving speeches include three for delivery in court and the three Tetralogies-imaginary intellectual exercises for display or teaching that consist of four speeches each, two on each side. All six of Antiphon's speeches concern homicide, probably because these stood at the beginning of the collection of his works. Fragments of some thirty other speeches cover many different topics.

- DEMOSTHENEs (384-322) is generally considered the best of the Attic orators. Although his nationalistic message is less highly regarded today, his powerful mastery of and ability to combine many different rhetorical styles continue to impress readers. Demosthenes was still a child when his wealthy father died. The trustees of the estate apparently misappropriated much of it, and when he came of age, he sued them in a series of cases (27-3I), regaining some of his fortune and making a name as a powerful speaker. He then wrote speeches for others in a variety of cases, public and private, and for his own use in court (where many cases involved major public issues), and in the Assembly, where he opposed the growing power of Philip of Macedon. The triumph of Philip and his son Alexander the Great eventually put an end to Demosthenes' career. Some sixty speeches have come down under his name, about a third of them of questionable authenticity.

- Dinarchus (ca. 360-ca. 290) was born in Corinth but spent much of his life in Athens as a metic (a noncitizen resident). 
His public fame came primarily from writing speeches for the prosecutions surrounding the Harpalus affair in 324, when several prominent figures (including Demosthenes) were accused of bribery. After 322 he had a profitable career as a logographer.

- Hyperides (389/8-322) was a political leader and logographer of so many different talents that he was called the pentathlete of orators. He was a leader of the Athenian resistance to Philip and Alexander and (like Demosthenes) was condemned to death after Athens' final surrender. One speech and substantial fragments of five others have been recovered from papyrus remains; otherwise, only fragments survive.

- ISAEUS (ca. 4I5-ca. 340) wrote speeches on a wide range of topics, but the eleven complete speeches that survive, dating from ca. 390 to ca. 344, all concern inheritance. As with Antiphon, the survival of these particular speeches may have been the result of the later ordering of his speeches by subject; we have part of a twelfth speech and fragments and titles of some forty other works. Isaeus is said to have been a pupil of Isocrates and the teacher of Demosthenes.

- isocrates (436-338) considered himself a philosopher and educator, not an orator or rhetorician. He came from a wealthy Athenian family but lost most of his property in the Peloponnesian War, and in 403 he took up logography. About 390 he abandoned this practice and turned to writing and teaching, setting forth his educational, philosophical, and political views in essays that took the form of speeches but were not meant for oral delivery. He favored accommodation with the growing power of Philip of Macedon and panhellenic unity. His school was based on a broad concept of rhetoric and applied philosophy; it attracted pupils from the entire Greek world (including Isaeus, Lycurgus, and Hyperides) and became the main rival of Plato's Academy. Isocrates greatly influenced education and rhetoric in the Hellenistic, Roman, and modern periods until the eighteenth century.

- LyCurgus (ca. 390-ca. 324) was a leading public official who restored the financial condition of Athens after 338 and played 
a large role in the city for the next dozen years. He brought charges of corruption or treason against many other officials, usually with success. Only one speech survives.

- Lysias (ca. 445-ca. 380) was a metic-an official resident of Athens but not a citizen. Much of his property was seized by the Thirty during their short-lived oligarchic coup in 404-403. Perhaps as a result he turned to logography. More than thirty speeches survive in whole or in part, though the authenticity of some is doubted. We also have fragments or know the titles of more than a hundred others. The speeches cover a wide range of cases, and he may have delivered one himself (Lys. I2), on the death of his brother at the hands of the Thirty. Lysias is particularly known for his vivid narratives, his èthopoiza, or "creation of character," and his prose style, which became a model of clarity and vividness.

\section{THE WORKS OF THE ORATORS}

As soon as speeches began to be written down, they could be preserved. We know little about the conditions of book "publication" (i.e., making copies for distribution) in the fourth century, but there was an active market for books in Athens, and some of the speeches may have achieved wide circulation. ${ }^{12}$ An orator (or his family) may have preserved his own speeches, perhaps to advertise his ability or demonstrate his success, or booksellers may have collected and copied them in order to make money.

We do not know how closely the preserved text of these speeches corresponded to the version actually delivered in court or in the Assembly. Speakers undoubtedly extemporized or varied from their text on occasion, but there is no good evidence that deliberative speeches were substantially revised for publication. ${ }^{13}$ In forensic oratory a logographer's reputation would derive first and

\footnotetext{
${ }^{12}$ Dover's discussion (1968) of the preservation and transmission of the works of Lysias (and perhaps others under his name) is useful not just for Lysias but for the other orators too. His theory of shared authorship between logographer and litigant, however, is unconvincing (see Usher 1976).

${ }^{13}$ See further Trevett 1996: 437-439.
} 
foremost from his success with jurors. If a forensic speech was victorious, there would be no reason to alter it for publication, and if it lost, alteration would probably not deceive potential clients. Thus, the published texts of forensic speeches were probably quite faithful to the texts that were provided to clients, and we have little reason to suspect substantial alteration in the century or so before they were collected by scholars in Alexandria (see below).

In addition to the speaker's text, most forensic speeches have breaks for the inclusion of documents. The logographer inserted a notation in his text-such as nomos ("law") or martyria ("testimony")—and the speaker would pause while the clerk read out the text of a law or the testimony of witnesses. Many speeches survive with only a notation that a nomos or martyria was read at that point, but in some cases the text of the document is included. It used to be thought that these documents were all creations of later scholars, but many (though not all) are now ac-

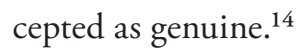

With the foundation of the famous library in Alexandria early in the third century, scholars began to collect and catalogue texts of the orators, along with many other classical authors. Only the best orators were preserved in the library, many of them represented by over Ioo speeches each (some undoubtedly spurious). Only some of these works survived in manuscript form to the modern era; more recently a few others have been discovered on ancient sheets of papyrus, so that today the corpus of Attic Oratory consists of about 150 speeches, together with a few letters and other works. The subject matter ranges from important public issues and serious crimes to business affairs, lovers' quarrels, inheritance disputes, and other personal or family matters.

In the centuries after these works were collected, ancient scholars gathered biographical facts about their authors, produced grammatical and lexicographic notes, and used some of the speeches as evidence for Athenian political history. But the ancient scholars who were most interested in the orators were those who studied prose style, the most notable of these being Diony-

\footnotetext{
${ }^{14}$ See MacDowell I990: 43-47; Todd I993: 44-45.
} 
sius of Halicarnassus (first century BC), who wrote treatises on several of the orators, ${ }^{15}$ and Hermogenes of Tarsus (second century AD), who wrote several literary studies, including On Types of Style. ${ }^{16}$ But relative to epic or tragedy, oratory was little studied; and even scholars of rhetoric whose interests were broader than style, like Cicero and Quintilian, paid little attention to the orators, except for the acknowledged master, Demosthenes.

Most modern scholars until the second half of the twentieth century continued to treat the orators primarily as prose stylists. ${ }^{17}$ The reevaluation of Athenian democracy by George Grote and others in the nineteenth century stimulated renewed interest in Greek oratory among historians; and increasing interest in Athenian law during that century led a few legal scholars to read the orators. But in comparison with the interest shown in the other literary genres - epic, lyric, tragedy, comedy, and even historyAttic oratory has been relatively neglected until the last third of the twentieth century. More recently, however, scholars have discovered the value of the orators for the broader study of Athenian culture and society. Since Dover's ground-breaking works on popular morality and homosexuality, ${ }^{18}$ interest in the orators has been increasing rapidly, and they are now seen as primary representatives of Athenian moral and social values, and as evidence for social and economic conditions, political and social ide-

\footnotetext{
${ }^{15}$ Dionysius' literary studies are collected and translated in Usher I974-I985.

${ }^{16}$ Wooten 1987. Stylistic considerations probably also influenced the selection of the "canon" of ten orators; see Worthington 1994.

${ }^{17}$ For example, the most popular and influential book ever written on the orators, Jebb's The Attic Orators (I875), was presented as an "attempt to aid in giving Attic Oratory its due place in the history of Attic Prose" (I.xiii). This modern focus on prose style can plausibly be connected to the large role played by prose composition (the translation of English prose into Greek, usually in imitation of specific authors or styles) in the Classics curriculum, especially in Britain.

${ }^{18}$ Dover (1974, 1978). Dover recently commented (1994: 157), "When I began to mine the riches of Attic forensic oratory I was astonished to discover that the mine had never been exploited."
} 
ology, and in general those aspects of Athenian culture that in the past were commonly ignored by historians of ancient Greece but are of increasing interest and importance today, including women and the family, slavery, and the economy.

\section{GOVERNMENT AND LAW IN CLASSICAL ATHENS}

The hallmark of the Athenian political and legal systems was its amateurism. Most public officials, including those who supervised the courts, were selected by lot and held office for a limited period, typically a year. Thus a great many citizens held public office at some point in their lives, but almost none served for an extended period of time or developed the experience or expertise that would make them professionals. All significant policy decisions were debated and voted on in the Assembly, where the quorum was 6,000 citizens, and all significant legal cases were judged by bodies of 200 to 500 jurors or more. Public prominence was not achieved by election (or selection) to public office but depended rather on a man's ability to sway the majority of citizens in the Assembly or jurors in court to vote in favor of a proposed course of action or for one of the litigants in a trial. Success was never permanent, and a victory on one policy issue or a verdict in one case could be quickly reversed in another. ${ }^{19}$ In such a system the value of public oratory is obvious, and in the fourth century, oratory became the most important cultural institution in Athens, replacing drama as the forum where major ideological concerns were displayed and debated.

Several recent books give good detailed accounts of Athenian government and law, ${ }^{20}$ and so a brief sketch can suffice here. The

\footnotetext{
${ }^{19}$ In the Assembly this could be accomplished by a reconsideration of the question, as in the famous Mytilenean debate (Thuc. 3.36-50); in court a verdict was final, but its practical effects could be thwarted or reversed by later litigation on a related issue.

${ }^{20}$ For government, see Sinclair 1988, Hansen I99I; for law, MacDowell 1978, Todd 1993, and Boegehold I995 (Bonner 1927 is still helpful). Much of our information about the legal and political systems comes from a work attributed to Aristotle but perhaps written by a pupil of his, The Athenian
} 
main policy-making body was the Assembly, open to all adult male citizens; a small payment for attendance enabled at least some of the poor to attend along with the leisured rich. In addition, a Council of 500 citizens, selected each year by lot with no one allowed to serve more than two years, prepared material for and made recommendations to the Assembly; a rotating subgroup of this Council served as an executive committee, the Prytaneis. Finally, numerous officials, most of them selected by lot for one-year terms, supervised different areas of administration and finance. The most important of these were the nine Archons (lit. "rulers"): the eponymous Archon after whom the year was named, the Basileus ("king"), ${ }^{21}$ the Polemarch, and the six Thesmothetae. Councilors and almost all these officials underwent a preliminary examination (dokimasia) before taking office, and officials submitted to a final accounting (euthynai) upon leaving; at these times any citizen who wished could challenge a person's fitness for his new position or his performance in his recent position.

There was no general taxation of Athenian citizens. Sources of public funding included the annual tax levied on metics, various fees and import duties, and (in the fifth century) tribute from allied cities; but the source that figures most prominently in the orators is the Athenian system of liturgies (leitourgiai), by which in a regular rotation the rich provided funding for certain special public needs. The main liturgies were the choregia, in which a sponsor (chorégos) supervised and paid for the training and performance of a chorus which sang and danced at a public festival, ${ }^{22}$ and the trierarchy, in which a sponsor (trierarch) paid to equip and usually commanded a trireme, or warship, for a year. Some of these liturgies required substantial expenditures, but even so, some men

Constitution (Ath. Pol.-conveniently translated with notes by Rhodes 1984). The discovery of this work on a papyrus in Egypt in I890 caused a major resurgence of interest in Athenian government.

${ }^{21}$ Modern scholars often use the term archōn basileus or "king archon," but Athenian sources (e.g., Ath. Pol. 57) simply call him the basileus.

${ }^{22}$ These included the productions of tragedy and comedy, for which the main expense was for the chorus. 
spent far more than required in order to promote themselves and their public careers, and litigants often tried to impress the jurors by referring to liturgies they had undertaken (see, e.g., Lys. 2I.I-5). A further twist on this system was that if a man thought he had been assigned a liturgy that should have gone to someone else who was richer than he, he could propose an exchange of property (antidosis), giving the other man a choice of either taking over the liturgy or exchanging property with him. Finally, the rich were also subject to special taxes (eisphorai) levied as a percentage of their property in times of need.

The Athenian legal system remained similarly resistant to professionalization. Trials and the procedures leading up to them were supervised by officials, primarily the nine Archons, but their role was purely administrative, and they were in no way equivalent to modern judges. All significant questions about what we would call points of law were presented to the jurors, who considered them together with all other issues when they delivered their verdict at the end of the trial. ${ }^{23}$ Trials were "contests" (agōnes) between two litigants, each of whom presented his own case to the jurors in a speech, plaintiff first, then defendant; in some cases each party then spoke again, probably in rebuttal. Since a litigant had only one or two speeches in which to present his entire case, and no issue was decided separately by a judge, all the necessary factual information and every important argument on substance or procedure, fact or law, had to be presented together. A single speech might thus combine narrative, argument, emotional appeal, and various digressions, all with the goal of obtaining a favorable verdict. Even more than today, a litigant's primary task was to control the issue-to determine which issues the jurors would consider most important and which questions they would have in their minds as they cast their votes. We only

${ }^{23}$ Certain religious "interpreters" (exēgètai) were occasionally asked to give their opinion on a legal matter that had a religious dimension (such as the prosecution of a homicide), but although these opinions could be reported in court (e.g., Dem. 47.68-73), they had no official legal standing. The most significant administrative decision we hear of is the refusal of the Basileus to accept the case in Antiphon 6 (see 6.37-46). 
rarely have both speeches from a trial, ${ }^{24}$ and we usually have little or no external evidence for the facts of a case or the verdict. We must thus infer both the facts and the opponent's strategy from the speech we have, and any assessment of the overall effectiveness of a speech and of the logographer's strategy is to some extent speculative.

Before a trial there were usually several preliminary hearings for presenting evidence; arbitration, public and private, was available and sometimes required. These hearings and arbitration sessions allowed each side to become familiar with the other side's case, so that discussions of "what my opponent will say" could be included in one's speech. Normally a litigant presented his own case, but he was often assisted by family or friends. If he wished (and could afford it), he could enlist the services of a logographer, who presumably gave strategic advice in addition to writing a speech. The speeches were timed to ensure an equal hearing for both sides, ${ }^{25}$ and all trials were completed within a day. Two hundred or more jurors decided each case in the popular courts, which met in the Agora. ${ }^{26}$ Homicide cases and certain other religious trials (e.g., Lys. 7) were heard by the Council of the Areopagus or an associated group of fifty-one Ephetae. The Areopagus was composed of all former Archons-perhaps 150-200 members at most times. It met on a hill called the Areopagus ("rock of Ares") near the Acropolis.

Jurors for the regular courts were selected by lot from those citizens who registered each year and who appeared for duty that day; as with the Assembly, a small payment allowed the poor to serve. After the speakers had finished, the jurors voted immediately without any formal discussion. The side with the majority won; a tie vote decided the case for the defendant. In some cases where the penalty was not fixed, after a conviction the ju-

${ }^{24}$ The exceptions are Demosthenes 19 and Aeschines 2, Aeschines 3 and Demosthenes I8, and Lysias 6 (one of several prosecution speeches) and Andocides I; all were written for major public cases.

${ }^{25}$ Timing was done by means of a water clock, which in most cases was stopped during the reading of documents.

${ }^{26}$ See Boegehold 1995 . 
rors voted again on the penalty, choosing between penalties proposed by each side. Even when we know the verdict, we cannot know which of the speaker's arguments contributed most to his success or failure. However, a logographer could probably learn from jurors which points had or had not been successful, so that arguments that are found repeatedly in speeches probably were known to be effective in most cases.

The first written laws in Athens were enacted by Draco (ca. 620) and Solon (ca. 590), and new laws were regularly added. At the end of the fifth century the existing laws were reorganized, and a new procedure for enacting laws was instituted; thereafter a group of Law-Givers (nomothetai) had to certify that a proposed law did not conflict with any existing laws. There was no attempt, however, to organize legislation systematically, and although Plato, Aristotle, and other philosophers wrote various works on law and law-giving, these were either theoretical or descriptive and had no apparent influence on legislation. Written statutes generally used ordinary language rather than precise legal definitions in designating offenses, and questions concerning precisely what constituted a specific offense or what was the correct interpretation of a written statute were decided (together with other issues) by the jurors in each case. A litigant might, of course, assert a certain definition or interpretation as "something you all know" or "what the lawgiver intended," but such remarks are evidently tendentious and cannot be taken as authoritative.

The result of these procedural and substantive features was that the verdict depended largely on each litigant's speech (or speeches). As one speaker puts it (Ant. 6.18), "When there are no witnesses, you (jurors) are forced to reach a verdict about the case on the basis of the prosecutor's and defendant's words alone; you must be suspicious and examine their accounts in detail, and your vote will necessarily be cast on the basis of likelihood rather than clear knowledge." Even the testimony of witnesses (usually on both sides) is rarely decisive. On the other hand, most speakers make a considerable effort to establish facts and provide legitimate arguments in conformity with established law. Plato's view of rhetoric as a clever technique for persuading an ignorant crowd that the false is true is not borne out by the speeches, and the le- 
gal system does not appear to have produced many arbitrary or clearly unjust results.

The main form of legal procedure was a dike ("suit") in which the injured party (or his relatives in a case of homicide) brought suit against the offender. Suits for injuries to slaves would be brought by the slave's master, and injuries to women would be prosecuted by a male relative. Strictly speaking, a dikē was a private matter between individuals, though like all cases, dikai often had public dimensions. The other major form of procedure was a graphe ("writing" or "indictment") in which "anyone who wished" (i.e., any citizen) could bring a prosecution for wrongdoing. Graphai were instituted by Solon, probably in order to allow prosecution of offenses where the victim was unable or unlikely to bring suit himself, such as selling a dependent into slavery; but the number of areas covered by graphai increased to cover many types of public offenses as well as some apparently private crimes, such as hybris.

The system of prosecution by "anyone who wished" also extended to several other more specialized forms of prosecution, like eisangelia ("impeachment"), used in cases of treason. Another specialized prosecution was apagogge ("summary arrest"), in which someone could arrest a common criminal (kakourgos, lit. "evildoer"), or have him arrested, on the spot. The reliance on private initiative meant that Athenians never developed a system of public prosecution; rather, they presumed that everyone would keep an eye on the behavior of his political enemies and bring suit as soon as he suspected a crime, both to harm his opponents and to advance his own career. In this way all public officials would be watched by someone. There was no disgrace in admitting that a prosecution was motivated by private enmity.

By the end of the fifth century the system of prosecution by "anyone who wished" was apparently being abused by so-called sykophants (sykophantai), who allegedly brought or threatened to bring false suits against rich men, either to gain part of the fine that would be levied or to induce an out-of-court settlement in which the accused would pay to have the matter dropped. We cannot gauge the true extent of this problem, since speakers usually provide little evidence to support their claims that their oppo- 
nents are sykophants, but the Athenians did make sykophancy a crime. They also specified that in many public procedures a plaintiff who either dropped the case or failed to obtain one-fifth of the votes would have to pay a heavy fine of I,0oo drachmas. Despite this, it appears that litigation was common in Athens and was seen by some as excessive.

Over the course of time, the Athenian legal and political systems have more often been judged negatively than positively. Philosophers and political theorists have generally followed the lead of Plato (427-347), who lived and worked in Athens his entire life while severely criticizing its system of government as well as many other aspects of its culture. For Plato, democracy amounted to the tyranny of the masses over the educated elite and was destined to collapse from its own instability. The legal system was capricious and depended entirely on the rhetorical ability of litigants with no regard for truth or justice. These criticisms have often been echoed by modern scholars, who particularly complain that law was much too closely interwoven with politics and did not have the autonomous status it achieved in Roman law and continues to have, at least in theory, in modern legal systems.

Plato's judgments are valid if one accepts the underlying presuppositions, that the aim of law is absolute truth and abstract justice and that achieving the highest good of the state requires thorough and systematic organization. Most Athenians do not seem to have subscribed to either the criticisms or the presuppositions, and most scholars now accept the long-ignored fact that despite major external disruptions in the form of wars and two shortlived coups brought about by one of these wars, the Athenian legal and political systems remained remarkably stable for almost two hundred years (508-320). Moreover, like all other Greek cities at the time, whatever their form of government, Athenian democracy was brought to an end not by internal forces but by the external power of Philip of Macedon and his son Alexander. The legal system never became autonomous, and the rich sometimes complained that they were victims of unscrupulous litigants, but there is no indication that the people wanted to yield control of the legal process to a professional class, as Plato recommended. For most Athenians-Plato being an exception in this and many 
other matters-one purpose of the legal system was to give everyone the opportunity to have his case heard by other citizens and have it heard quickly and cheaply; and in this it clearly succeeded.

Indeed, the Athenian legal system also served the interests of the rich, even the very rich, as well as the common people, in that it provided a forum for the competition that since Homer had been an important part of aristocratic life. In this competition, the rich used the courts as battlegrounds, though their main weapon was the rhetoric of popular ideology, which hailed the rule of law and promoted the ideal of moderation and restraint. ${ }^{27}$ But those who aspired to political leadership and the honor and status that accompanied it repeatedly entered the legal arena, bringing suit against their political enemies whenever possible and defending themselves against suits brought by others whenever necessary. The ultimate judges of these public competitions were the common people, who seem to have relished the dramatic clash of individuals and ideologies. In this respect fourth-century oratory was the cultural heir of fifth-century drama and was similarly appreciated by the citizens. Despite the disapproval of intellectuals like Plato, most Athenians legitimately considered their legal system a hallmark of their democracy and a vital presence in their culture.

\section{THE TRANSLATION OF GREEK ORATORY}

The purpose of this series is to provide students and scholars in all fields with accurate, readable translations of all surviving classical Attic oratory, including speeches whose authenticity is disputed, as well as the substantial surviving fragments. In keeping with the originals, the language is for the most part nontechnical. Names of persons and places are given in the (generally more familiar) Latinized forms, and names of officials or legal procedures have been translated into English equivalents, where possible. Notes are intended to provide the necessary historical and cultural background; scholarly controversies are generally not dis-

\footnotetext{
${ }^{27}$ Ober 1989 is fundamental; see also Cohen 1995.
} 
cussed. The notes and introductions refer to scholarly treatments in addition to those listed below, which the reader may consult for further information.

Cross-references to other speeches follow the standard numbering system, which is now well established except in the case of Hyperides (for whom the numbering of the Oxford Classical Text is used). ${ }^{28}$ References are by work and section (e.g., Dem. 24.73); spurious works are not specially marked; when no author is named (e.g., 24.73), the reference is to the same author as the annotated passage.

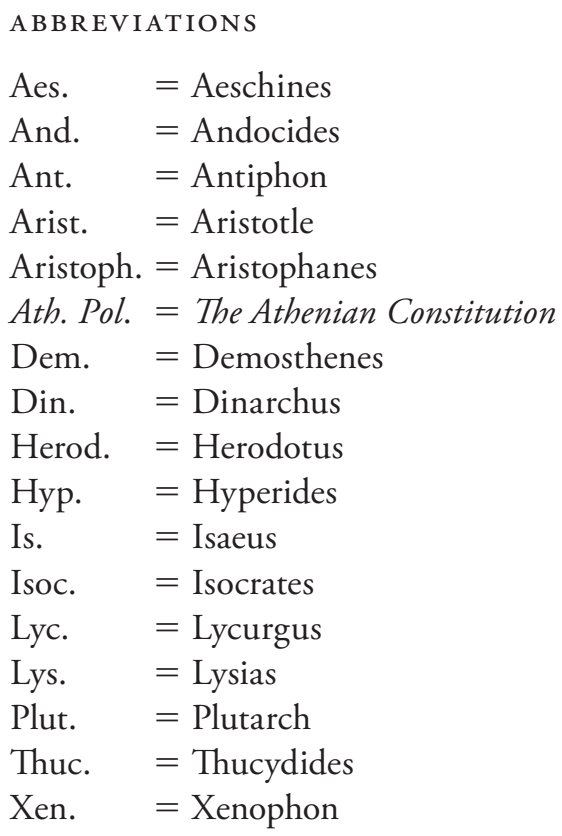

NOTE ON CURRENCY: The main unit of Athenian currency was the drachma; this was divided into obols and larger amounts were designated minas and talents.

\footnotetext{
${ }^{28}$ For a listing of all the orators and their works, with classifications (forensic, deliberative, epideictic) and rough dates, see Edwards I994: 74-79.
} 
I drachma $=6$ obols

I mina $=$ Ioo drachmas

I talent $=60$ minas $(6,000$ drachmas $)$

It is impossible to give an accurate equivalence in terms of modern currency, but it may be helpful to remember that the daily wage of some skilled workers was a drachma in the mid-fifth century and $2-2 \frac{1}{2}$ drachmas in the later fourth century. Thus it may not be too misleading to think of a drachma as worth about $\$ 50$ or $£ 33$ and a talent as about $\$ 300,000$ or $£ 200,000$ in 1997 currency.

\section{BIBLIOGRAPHY OF WORKS CITED}

Boegehold, Alan L., 1995: The Lawcourts at Athens: Sites, Buildings, Equipment, Procedure, and Testimonia. Princeton.

Bonner, Robert J., 1927: Lawyers and Litigants in Ancient Athens. Chicago.

Carey, Christopher, 1997: Trials from Classical Athens. London.

Cohen, David, 1995: Law, Violence and Community in Classical Athens. Cambridge.

Cole, Thomas, 1991: The Origins of Rhetoric in Ancient Greece. Baltimore.

Dover, Kenneth J., 1968: Lysias and the Corpus Lysiacum. Berkeley.

- 1974: Greek Popular Morality in the Time of Plato and Aristotle. Oxford.

- 1978: Greek Homosexuality. London.

- 1994: Marginal Comment. London.

Edwards, Michael, 1994: The Attic Orators. London.

Gagarin, Michael, and Paul Woodruff, 1995: Early Greek Political Thought from Homer to the Sophists. Cambridge.

Hansen, Mogens Herman, I99I: The Athenian Democracy in the Age of Demosthenes. Oxford.

Jebb, Richard, I875: The Attic Orators, 2 vols. London.

Kennedy, George A., 1963: The Art of Persuasion in Greece. Princeton.

Kerferd, G. B., I98I: The Sophistic Movement. Cambridge. 
MacDowell, Douglas M., 1978: The Law in Classical Athens. London.

- ed. 1990: Demosthenes, Against Meidias. Oxford.

Ober, Josiah, 1989: Mass and Elite in Democratic Athens. Princeton.

Rhodes, P. J., trans., 1984: Aristotle, The Athenian Constitution. Penguin Books.

Sinclair, R. K., 1988: Democracy and Participation in Athens. Cambridge.

Todd, Stephen, 1993: The Shape of Athenian Law. Oxford.

Trevett, Jeremy, 1992: Apollodoros the Son of Pasion. Oxford.

—, 1996: "Did Demosthenes Publish His Deliberative Speeches?" Hermes I24: 425-44I.

Usher, Stephen, 1976: "Lysias and His Clients," Greek, Roman and Byzantine Studies 17: 3I-40.

, trans., 1974-1985: Dionysius of Halicarnassus, Critical Essays. 2 vols. Loeb Classical Library. Cambridge, MA.

- 1999: Greek Oratory: Tradition and Originality. Oxford.

Wooten, Cecil W., trans., 1987: Hermogenes' On Types of Style. Chapel Hill, NC.

Worthington, Ian, 1994: "The Canon of the Ten Attic Orators," in Persuasion: Greek Rhetoric in Action, ed. Ian Worthington. London: 244-263.

Yunis, Harvey, 1996: Taming Democracy: Models of Political Rhetoric in Classical Athens. Ithaca, NY. 
DEMOSTHENES, SPEECHES 1-17 
THIS PAGE INTENTIONALLY LEFT BLANK 